\title{
Evaluasi Kinerja Daun Meniran dan Daun Seledri Pada Darah, Hati dan Ginjal dengan Menggunakan Metode Response Surface
}

\author{
Joko Purwadi ${ }^{1}$, Sugiyarto ${ }^{2}$, Rosiana Aprilia ${ }^{3}$ \\ 1,23 Prodi Matematika, Universitas Ahmad Dahlan \\ Jl. Ringroad Selatan, Kragilan, Tamanan, Kec. Banguntapan, Bantul, Yogyakarta 55191 \\ Email: joko@math.uad.ac.id ${ }^{1}$, sugiyarto@math.uad.ac.id², rosiana1311015033@webmail.uad.ac.id ${ }^{3}$ \\ *Korespondensi penulis : joko@math.uad.ac.id
}

\begin{abstract}
Abstrak
Penelitian ini membahas megenai evaluasi kinerja daun Meniran $\left(X_{1}\right)$ dan daun Seledri $\left(X_{2}\right)$ pada organ darah, hati dan ginjal. Sampel pada daun Meniran dan daun Seledri masing-masing diambil sebesar $100 \mathrm{mg} / \mathrm{BB}$ dan $50 \mathrm{mg} / \mathrm{BB}$. Metode yang digunakan pada penelitian adalah metode response surface. Penelitian ini dilakukan dua tahap, yaitu eksperimen orde I merupakan tahap penyaringan faktor (screening) dan ekperimen orde II yang merupakan tahap optimalisasi. Hasil penelitian menunjukkan bahwa model yang sesuai dan menghasilkan model yang optimal yaitu pada organ darah pada komponen trombosit $\left(Y_{9}\right)$ dan pada komponen Neutrofil $\left(Y_{12}\right)$. Kondisi optimal pada komponen trombosit $\left(Y_{9}\right)$ memberikan respon sebesar 1020611 / $\mu l$ dengan kombinasi Meniran sebesar $67 \mathrm{mg} / \mathrm{BB}$ dan Seledri sebesar $63 \mathrm{mg} / \mathrm{BB}$, sedangkan kondisi optimal pada komponen Neutrofil $\left(Y_{12}\right)$ sebesar $34 \mathrm{mcl}$ kombinasi Meniran sebesar $57 \mathrm{mg} / \mathrm{BB}$ dan Seledri sebesar $51 \mathrm{mg} / \mathrm{BB}$.
\end{abstract}

Kata Kunci: Metode Respon Surface, daun Seledri, daun Meniran, Optimasi.

\begin{abstract}
This study discusses the performance evaluation of Meniran leaves $\left(X_{1}\right)$ and Celery leaves $\left(X_{2}\right)$ in the organs of the blood, liver and kidneys. Samples of Meniran and Celery leaves were taken at $100 \mathrm{mg} / \mathrm{BW}$ and $50 \mathrm{mg} / \mathrm{BW}$, respectively. The method used in this research is the response surface method. This research was conducted in two stages, namely the first order experiment which was the factor screening stage and the second order experiment which was the optimization stage. The results showed that the appropriate model and the optimal model were the blood organs in the Trombosit component $\left(Y_{9}\right)$ and the Neutrophil component $\left(Y_{12}\right)$. The optimal conditions for the Trombosit component $\left(Y_{9}\right)$ gave a response of $1020611 / \mu \mathrm{l}$ with a combination of Meniran at $67 \mathrm{mg} / \mathrm{BW}$ and Celery at $63 \mathrm{mg} / \mathrm{BW}$, while the optimal conditions for the Neutrophil component $\left(Y_{12}\right)$ ) was $34 \mathrm{mcl}$, a combination of Meniran at $57 \mathrm{mg} / \mathrm{BW}$ and Celery by $51 \mathrm{mg} / \mathrm{BW}$.
\end{abstract}

Keywords: Consists of 3 to 5 specific words or phrases, reflecting the contents of the article, Palatino Linotype, 10pt, and avoid using abbreviations. 


\section{Pendahuluan}

Pengobatan herbal dewasa ini telah menjadi alternatif untuk penyembuhan penyakit dengan biaya yang lebih murah. Daun Seledri dan daun Meniran merupakan salah satu dari sekian banyak bahan pokok yang biasa digunakan untuk obat herbal yang ampuh untuk menangani beberapa penyakit antara lain hipertensi, antioksidan, diabetes dan masih banyak lagi. Berdasarkan penelitian yang dilakukan [1] daun Seledri mengandung beberapa zat yang menurunkan tekanan darah, Seledri juga memiliki kandungan bahan alami untuk menurunkan kadar kolesterol di dalam darah. Menurut [2] daun Meniran juga memiliki khasiat dalam penurunan kadar glukosa darah.

Kombinasi antara daun Meniran dan daun Seledri menjadi hal yang menarik untuk diteliti selanjutnya. Bagiamana kombinasi optmial anatara kedua bahan herbal tersebut akan membantu dalam proses penyembuhan suatu penyakit. Metode yang akan digunakan untuk menguji kombinasi antara kedua bahan adalah metode response surface. Metode response surface memiliki kelebihan antara lain desain ini lebih efisien dengan jumlah runs percobaan lebih sedikit, sehingga dalam percobaan dapat lebih efektif. Beberapa penelitian yang pernah dilakukan salah satunya yaitu analisis kondisi optimum pencahayaan, kebisingan dan temperatur dengan metode response surface [3]. Penelitian yang dilakukan oleh [4] pada respon oil-film friction menggunakan metode response surface memberikan hasil yang baik dan dapat memprediksikan dengan tepat. Penelitian yang dilakukan oleh [5] menerapkan metode response surface untuk optimalisasi laba penjualan tanaman kangkung darat. Pernah diteliti pula oleh [6] bagaimana penerapan metode response surface untuk optimalisasi kondisi Proses Pengolahan Alkali Treated Cottonii (ACT). Penelitian yang menggabungkan kombinasi daun Meniran dan daun Seledri dan mencari kombinasi yang optimal dari keduanya belum pernah dilakukan sebelumnya. Sehingga perlu dilakukan penelitian dan diuji bagaimanakah evaluasi kinerja dari kedua daun dengan menggunakan metode response surface pada organ darah, hati dan ginjal.

Menurut [7] dijelaskan bahwa metode response surface, merupakan kumpulan teknik matematis dan statistik yang digunakan untuk pemodelan dan analisis masalah dalam suatu respon yang dipengaruhi oleh beberapa variabel dan tujuannya adalah untuk mengoptimasi respon yang dimaksud. Metode permukaan respon bertujuan untuk membantu peneliti dalam melakukan improvisasi untuk mendapatkan hasil optimum secara tepat dan efisien. Setelah daerah percobaan ditemukan, model respon dengan tingkat ketepatan lebih tinggi dapat digunakan untuk mendapatkan nilai variabel sebenarnya yang akan menghasilkan respon optimum. Metode ini memberikan kemudahan dalam menentukan kondisi proses optimum baik pada sistem maupun pada jarak faktor yang dibutuhkan untuk mendapatkan hasil yang sangat memuaskan [8].

Adapun tujuan dari penelitian ini adalah penentuan kondisi optimum dari pemberian kombinasi dosis Meniran dan daun Seledri yang diujicobakan terhadap Mencit. Dari sampel darah yang diambil akan diteliti efek pemberian dosis dari kedua kombinasi daun pada organ darah, hati dan ginjal, serta akan ditentukan variabel yang paling berpengaruh terhadap kinerja darah, hati dan ginjal sehingga terjadi efektifitas kerja dengan pedekatan metode response surface.

\section{Metode Penelitian}

Metode response surface merupakan suatu kumpulan dari teknik-teknik statistika dan matematika yang berguna untuk menganalisis permasalahan tentang beberapa variabel bebas yang mempengaruhi variabel tak bebas dari respon, serta bertujuan mengoptimumkan respon. Dengan demikian, metodologi permukaan respon dapat dipergunakan oleh peneliti 
untuk mencari suatu fungsi pendekatan yang cocok untuk meramalkan respon yang akan datang dan menentukan nilai-nilai variabel bebas yang mengoptimumkan respon yang telah dipelajari [7].

Langkah dari Metode response surface adalah menemukan hubungan antara respon $y$ dan faktor $x$ melalui persamaan polinomial orde pertama dan digunakan model regresi linear, atau yang lebih dikenal dengan first-order model (model orde I), yaitu:

dengan:

$$
Y_{i}=\beta_{0}+\sum_{i=1}^{k} \beta_{i} X_{i}+\varepsilon_{i}
$$

$Y_{i}=$ Variabel Dependen; $X_{i}=$ Variabel Independent; $\beta_{i}=$ parameter $; \varepsilon_{i}=$ Galat; $i=1, \ldots, k$.

Rancangan eksperimen orde pertama yang sesuai adalah rancangan faktorial $2^{k}$ (Two Level Factorial Design). Selanjutnya untuk model orde II, biasanya terdapat kelengkungan dan digunakan model polynomial orde kedua yang fungsinya kuadratik:

dengan :

$$
Y_{i}=\beta_{0}+\sum_{i=1}^{k} \beta_{i} X_{i}+\sum_{i=1}^{k} \beta_{i i} X_{i}^{2}+\sum \sum_{i<j} \beta_{i j} X_{i} X_{j}+\varepsilon
$$

$Y_{i}=$ Variabel Dependen; $X_{i}=$ Variabel Independent; $\beta_{i}=$ parameter $; \varepsilon_{i}=$ Galat; $i=1, \ldots, k$.

Rancangan eksperimen orde II yang digunakan adalah rancangan faktorial $3^{k}$ (Three Level Factorial Design), yang sesuai dengan masalah optimasi. Kemudian dari model orde II ditemukan titik stasioner dan model optimasinya. Analisis pencocokan permukaan respon orde II sering disebut sebagai analisis kanonik. Metode kuadrat terkecil digunakan untuk mengestimasi parameter-parameter pada fungsi-fungsi aproksimasi tersebut.

Rancangan komposit pusat adalah rancangan faktorial $\left(2^{k}\right)$ yang diperluas melalui penambahan titik-titik pengamatan pada pusat agar memungkinkan pendugaan koefisien parameter response survace ordo kedua. Maka rancangan komposit pusat dapat dipandang sebagai suatu rancangan faktorial $2^{k}$ (factional factorial), yang diperluas dengan matriks tambahan berikut:

$$
\left[\begin{array}{ccccc}
X_{1} & X_{2} & X_{3} & \cdots & X_{k} \\
0 & 0 & 0 & \cdots & 0 \\
-\alpha & 0 & 0 & \cdots & 0 \\
\alpha & 0 & 0 & \cdots & 0 \\
0 & -\alpha & 0 & \cdots & 0 \\
0 & \alpha & 0 & \cdots & 0 \\
0 & 0 & -\alpha & \cdots & 0 \\
0 & 0 & \alpha & \cdots & 0 \\
\cdots & \cdots & \cdots & \cdots & \cdots \\
\vdots & \vdots & \vdots & \cdots & \vdots \\
0 & 0 & 0 & \cdots & -\alpha \\
0 & 0 & 0 & \cdots & \alpha
\end{array}\right]
$$

Penggunaan nilai $\alpha$ dalam rancangan ini digunakan untuk menentukan kemungkinan adanya lengkungan respon percobaan pada rancangan sehingga model ordo kedua dapat diduga.

Pada umumnya nilai $\alpha$ ditentukan sebagai berikut: $\alpha=2^{k / 4}$, untuk ulangan penuh dan $\alpha=2^{(k-1) / 4}$, untuk setengah ulangan [10]. Ulangan penuh adalah jika semua kombinasi level fakor dilakukan percobaan untuk pengamatan respon. Jika dari seluruh kombinasi level faktor hanya dilakukan sebagian, maka dikatakan percobaan setengah ulangan. Secara umum peneliti 
boleh mendefinisikan rancangan komposit pusat sebagai rancangan percobaan faktorial $2^{k}$ atau faktorial sebagian $( \pm, 0,0, \ldots, 0),(0, \pm, 0, \ldots, 0), \ldots,(0,0,0, \ldots, \pm)$ serta $n_{0}$ titik pusat $(0,0, \ldots, 0) . n_{0}$ adalah konstata tertentu, dengan pemilihan $n_{0}$ yang tepat akan membuat rancangan komposit pusat bersifat orthogonal sehingga menjadikan suatu rancangan yang memiliki ketelitian seragam.

Dalam rancangan yang memiliki ketelitian seragam akan menghasilkan ragam dari $\bar{Y}$ pada titik asal. Parameter rancangan untuk rancangan komposit pusat dapat diputar yang bersifat orthogonal dan yang bersifat memiliki ketelitian yang seragam. Model yang akan diduga sebagai berikut:

$$
Y=\beta_{0}+\sum_{i=1}^{k} \beta_{i} X_{i} \sum_{i=1}^{k} \beta_{i i} X_{i}^{2}+\sum_{i} \sum_{j} \beta_{i i} X_{i} X_{j}+\varepsilon \text { dan } i>j
$$

maka dapat ditentukan kondisi maksimum dari $X$ jika memenuhi syarat perlu dan syarat cukup sebagai berikut :

i. $\quad$ Syarat perlu

$$
\frac{\partial \hat{Y}}{\partial X_{i}}=0 \text {, dengan } i=1,2,3, \ldots, k
$$

ii. Syarat khusus

dengan $\hat{Y}$ merupakan model regresi dugaan dari $Y$.

Determinan minor utama dari matriks Hessian $(\mathrm{H})$ bersifat definit negatif, jika hanya terdapat dua variabel $X_{1}$ dan $X_{2}$, maka matriks Hessian dapat didefinisikan sebagai:

$$
H=\left[\begin{array}{cc}
\frac{\partial^{2} \hat{Y}}{\partial X_{1}^{2}} & \frac{\partial^{2} \hat{Y}}{\partial X_{1} \partial X_{2}} \\
\frac{\partial^{2} \hat{Y}}{\partial X_{2} \partial X_{1}} & \frac{\partial^{2} \hat{Y}}{\partial X_{2}^{2}}
\end{array}\right]
$$

Jika terdapat lebih dari dua variabel, misalnya $X_{1}, X_{2}, X_{3}, \ldots, X_{k}$ maka bentuk matriks Hessian sebagai berikut:

$$
H=\left[\begin{array}{cccc}
\frac{\partial^{2} \hat{Y}}{\partial X_{1}^{2}} & \frac{\partial^{2} \hat{Y}}{\partial X_{1} \partial X_{2}} & \cdots & \frac{\partial^{2} \hat{Y}}{\partial X_{1} \partial X_{i}} \\
\frac{\partial^{2} \hat{Y}}{\partial X_{2} X_{1}} & \frac{\partial^{2} \hat{Y}}{\partial X_{2}^{2}} & \cdots & \frac{\partial^{2} \hat{Y}}{\partial X_{2} \partial X_{j}} \\
\vdots & \vdots & \ddots & \vdots \\
\frac{\partial^{2} \hat{Y}}{\partial X_{j} \partial_{1}} & \frac{\partial^{2} \hat{Y}}{\partial X_{i} \partial_{2}} & \cdots & \frac{\partial^{2} \hat{Y}}{\partial X_{i j}^{2}}
\end{array}\right]
$$

Sifat-sifat matriks Hessian dalam penentuan titik optimal yaitu sebagai berikut:

Jika determinan minor dari matriks Hessian bersifat definit negatif, maka titik stasioner yang diperoleh merupakan titik optimal maksimum. Jika determinan minor dari matriks Hessian bersifat definit positif, maka titik stasioner yang diperoleh merupakan titik optimal minimum.

\section{Hasil dan Pembahasan}

Data yang digunakan dalam penelitian yaitu tingkatan kombinasi kadar dosis Meniran dan Seledri yang bertujuan untuk menemukan kombinasi optimal terhadap organ yaitu darah, hati, dan ginjal yang lebih baik.

Dosis Meniran $\left(X_{1}\right)$ yang digunakan pada penelitian ini adalah $100 \mathrm{mg} / \mathrm{KgBB}$ dan $50 \mathrm{mg} /$ $\mathrm{KgBB}$, demikian juga dengan kadar Seledri $\left(X_{2}\right)$ digunakan pula dosis $100 \mathrm{mg} / \mathrm{KgBB}$ dan $50 \mathrm{mg} /$ KgBB. Pengulangan dari setiap faktor dilakukan sebanyak 4 kali untuk mengetahui bagaimana 
keragaman yang muncul dan selanjutnya akan digunakan metode response surface untuk optimasinya. Penelitian ini dilakukan pada tingkat $\alpha=0.05$.

Menggunakan softwerwe Minitab 17, maka diperoleh model ordo pertama secara lengkap sebagai berikut :

Tabel 1. Data Analisis Varian Ordo Pertama untuk masing - masing komponen Darah, Hati, Ginjal

\begin{tabular}{|c|c|c|}
\hline Model Ordo Pertama & $R^{2}$ & $P_{\text {value }}$ \\
\hline \multicolumn{3}{|l|}{ Komponen Darah *) } \\
\hline$Y_{1}=12.5-0.022 X_{1}+0.029 X_{2}$ & 0.081 & 0.959 \\
\hline$Y_{2}=7.05-0.0121 X_{1}+0.0163 X_{2}$ & 0.085 & 0.957 \\
\hline$Y_{3}=37.0-0.084 X_{1}+0.090 X_{2}$ & 0.130 & 0.933 \\
\hline$Y_{4}=69-2.38 X_{1}+2.36 X_{2}$ & 0.675 & 0.570 \\
\hline$Y_{5}=45.8-0.027 X_{1}+0.010 X_{2}$ & 0.015 & 0.992 \\
\hline$Y_{6}=15.5-0.0025 X_{1}+0.0015 X_{2}$ & 0.001 & 1.000 \\
\hline$Y_{7}=29.5+0.0143-0.003 X_{2}$ & 0.005 & 0.998 \\
\hline$Y_{8}=15.9-0.009 X_{1}+0.008 X_{2}$ & 0.011 & 0.994 \\
\hline$Y_{9}=715438-232 X_{1}-152 X_{2}$ & 0.005 & 0.997 \\
\hline$Y_{10}=67.0-0.170 X_{1}-0.055 X_{2}$ & 0.153 & 0.920 \\
\hline$Y_{11}=11.44+0.0025 X_{1}-0.0575 X_{2}$ & 0.386 & 0.783 \\
\hline$Y_{12}=8.31+0.1375 X_{1}+0.1275 X_{2}$ & 0.991 & 0.093 \\
\hline$Y_{13}=0.75+0.0300 X_{1}-0.0150 X_{2}$ & 0.918 & 0.286 \\
\hline \multicolumn{3}{|l|}{ Komponen Hati ${ }^{* *}$ ) } \\
\hline$Y_{1}=106.6+0.729 X_{1}-0.127 X_{2}$ & 0.867 & 0.365 \\
\hline$Y_{2}=66.49+0.1782-0.2013 X_{2}$ & 0.976 & 0.155 \\
\hline$Y_{3}=71.81+0.3475 X_{1}-0.2075 X_{2}$ & 0.977 & 0.153 \\
\hline$Y_{4}=95.9-0.230 X_{1}-0.160 X_{2}$ & 0.696 & 0.551 \\
\hline$Y_{5}=19.63+0.1600 X_{1}-0.0300 X_{2}$ & 0.897 & 0.320 \\
\hline$Y_{6}=13.06+0.0025 X_{1}-0.0375 X_{2}$ & 0.651 & 0.591 \\
\hline$Y_{7}=0.569-0.00075 X_{1}-0.00225 X_{2}$ & 0.526 & 0.688 \\
\hline \multicolumn{3}{|l|}{ Komponen Ginjal ***) } \\
\hline$Y_{1}=-19.7+0.364 X_{1}+0.218 X_{2}$ & 0.829 & 0.365 \\
\hline$Y_{2}=-0.299+0.00877 X_{1}+0.00468 X_{2}$ & 0.761 & 0.155 \\
\hline$Y_{3}=-0.8688+0.007750 X_{1}-0.003250 X_{2}$ & 0.999 & 0.153 \\
\hline
\end{tabular}

Keterangan:

*) Organ Darah : $Y_{1}:$ Hemoglobin $(\mathrm{HGB})^{\wedge}, Y_{2}:$ Eritrosit $(\mathrm{RBC})^{\wedge}, Y_{3}:$ Hematokrit, $Y_{4}:$ Lekosit $(\mathrm{WBC})^{\wedge} Y_{5}: \mathrm{MCH}^{\wedge} Y_{6}$ : $\operatorname{MCHC}^{\wedge} Y_{7}$ :RDW $Y_{8}$ : Trombosit $(\mathrm{PLT})^{\wedge}, Y_{9}$ : Limfosit, $Y_{10}$ : Monosit, $Y_{11}$ : Neutrofil, $Y_{12}$ : Eosinofil, $Y_{13}$ : Basofil **) Organ Hati: $Y_{1}$ : SGOT/AST, $Y_{2}$ : SGPT/ALT, $Y_{3}:$ Cholesterol, $Y_{4}$ : Trigliserida, $Y_{5}$ : HDL Chol Direk, $Y_{6}$ : LDL Chol Direk ${ }^{\wedge}, Y_{7}:$ Rasio LDL/HDL

***) Organ Ginjal : $Y_{1}$ : Bun / Urea Nitrogen, $Y_{2}$ : Creatinin, $Y_{3}$ Asam Urat

Berdasarkan Tabel 1 diperoleh bahwa semua $P_{\text {value }}$ lebih besar dari derajat signifikansi $\alpha=5 \%$ yang berarti bahwa model yang diperoleh tidak dapat menggambarkan secara baik kondisi sebenarnya. Oleh sebab itu dilakukan eksperimen yang kedua menggunakan persamaan regresi ordo kedua yang disajikan pada tabel berikut: 
Tabel 2. Data Analisis Varian Ordo Kedua untuk masing - masing komponen Darah, Hati, Ginjal

\begin{tabular}{|c|c|c|}
\hline Model ordo ke dua & $R^{2}$ & $P_{\text {value }}$ \\
\hline \multicolumn{3}{|l|}{ Komponen Darah *) } \\
\hline$Y_{1}=16.16-4.50 X_{1}-1.99 X_{2}-3.81 X_{1}^{2}-2.46 X_{2}^{2}-3.08 X_{1} X_{2}$ & 0.857 & $0.007^{*}$ \\
\hline$Y_{2}=9.068-2.578 X_{1}-1.249 X_{2}-2.090 X_{1}^{2}-1.272 X_{2}^{2}-1.700 X_{1} X_{2}$ & 0.864 & $0.006^{*}$ \\
\hline$Y_{3}=45.40-13.91 X_{1}-5.89 X_{2}-9.86 X_{1}^{2}-6.01 X_{2}^{2}-8.42 X_{1} X_{2}$ & 0.843 & $0.010^{*}$ \\
\hline$Y_{4}=8.9-121.8 X_{1}+118.0 X_{2}+56.8 X_{1}^{2}+60.0 X_{2}^{2}-239 X_{1} X_{2}$ & 0.598 & 0.183 \\
\hline$Y_{5}=50.06-16.28 X_{1}-5.49 X_{2}-11.79 X_{1}^{2}+0.41 X_{2}^{2}-12.60 X_{1} X_{2}$ & 0.901 & $0.002^{*}$ \\
\hline$Y_{6}=17.82-5.271 X_{1}-1.911 X_{2}-4.53 X_{1}^{2}-0.31 X_{2}^{2}-4.47 X_{1} X_{2}$ & 0.904 & $0.002^{*}$ \\
\hline$Y_{7}=35.56-9.79 X_{1}-4.32 X_{2}-9.49 X_{1}^{2}-0.84 X_{2}^{2}-8.90 X_{1} X_{2}$ & 0.914 & $0.001^{*}$ \\
\hline$Y_{8}=18.80-5.56 X_{1}-2.61 X_{2}-4.36 X_{1}^{2}-1.51 X_{2}^{2}-4.15 X_{1} X_{2}$ & 0.899 & $0.002^{*}$ \\
\hline $\begin{array}{c}Y_{9}=778000-155455 X_{1}-34099 X_{2}-232500 X_{1}^{2}+46500 X_{2}^{2} \\
-345000 X_{1} X_{2}\end{array}$ & 0.818 & $0.016^{*}$ \\
\hline$Y_{10}=57.40-14.06 X_{1}-8.92 X_{2}-15.51 X_{1}^{2}-2.26 X_{2}^{2}-7.50 X_{1} X_{2}$ & 0.650 & 0.122 \\
\hline$Y_{11}=9.20-2.09 X_{1}-0.32 X_{2}-3.10 X_{1}^{2}-0.60 X_{2}^{2}-2.00 X_{1} X_{2}$ & 0.598 & 0.183 \\
\hline$Y_{12}=31.60-12.44 X_{1}-2.40 X_{2}-7.17 X_{1}^{2}+3.33 X_{2}^{2}-15.50 X_{1} X_{2}$ & 0.842 & $0.010^{*}$ \\
\hline$Y_{13}=1.80-1.591 X_{1}-0.854 X_{2}+0.788 X_{1}^{2}-0.462 X_{2}^{2}-0.00 X_{1} X_{2}$ & 0.480 & 0.364 \\
\hline \multicolumn{3}{|l|}{ Komponen Hai **) } \\
\hline$Y_{1}=160.3-27.5 X_{1}-8.0 X_{2}-5.0 X_{1}^{2}+3.7 X_{2}^{2}-41.9 X_{1} X_{2}$ & 0.740 & 0.628 \\
\hline$Y_{2}=67.66-13.47 X_{1}-3.73 X_{2}-4.25 X_{1}^{2}+0.30 X_{2}^{2}-21.4 X_{1} X_{2}$ & 0.526 & 0.287 \\
\hline$Y_{3}=83.2-9.11 X_{1}-10.01 X_{2}-4.04 X_{1}^{2}+4.71 X_{2}^{2}-30.0 X_{1} X_{2}$ & 0.558 & 0.239 \\
\hline$Y_{4}=61.6-11.94 X_{1}-8.81 X_{2}+10.3 X_{1}^{2}-0.7 X_{2}^{2}-31.5 X_{1} X_{2}$ & 0.540 & 0.265 \\
\hline$Y_{5}=30.20-4.43 X_{1}-4.09 X_{2}-0.73 X_{1}^{2}+1.28 X_{2}^{2}-12.50 X_{1} X_{2}$ & 0.717 & 0.065 \\
\hline$Y_{6}=10.40-0.99 X_{1}-1.13 X_{2}-0.95 X_{1}^{2}+0.30 X_{2}^{2}-2.75 X_{1} X_{2}$ & 0.393 & 0.527 \\
\hline $\begin{aligned} Y_{7}=0.3400- & 0.0146 X_{1}-0.0323 X_{2}-0.0388 X_{1}^{2}-0.0138 X_{2}^{2} \\
& -0.0500 X_{1} X_{2}\end{aligned}$ & 0.208 & 0.856 \\
\hline \multicolumn{3}{|l|}{ Komponen Ginjal ***) } \\
\hline$Y_{1}=37.90-3.38 X_{1}+1.05 X_{2}-8.85 X_{1}^{2}-9.95 X_{2}^{2}-9.9 X_{1} X_{2}$ & 0.331 & 0.645 \\
\hline$Y_{2}=1.050-0.076 X_{1}+0.025 X_{2}-0.234 X_{1}^{2}-0.246 X_{2}^{2}-0.193 X_{1} X_{2}$ & 0.306 & 0.691 \\
\hline$Y_{3}=1.320-0.152 X_{1}-0.003 X_{2}-0.197 X_{1}^{2}+0.077 X_{2}^{2}-0.225 X_{1} X_{2}$ & 0.254 & 0.784 \\
\hline \multicolumn{3}{|c|}{$\begin{array}{l}\text { Keterangan: } \\
\quad{ }^{*} \text { Organ Darah }: Y_{1}: \text { Hemoglobin }(\mathrm{HGB})^{\wedge}, Y_{2}: \text { Eritrosit }(\mathrm{RBC})^{\wedge}, Y_{3}: \text { Hematokrit, } Y_{4}: \text { Lekosit }(\mathrm{WBC})^{\wedge} Y_{5}: \mathrm{MCH}^{\wedge} Y_{6}: \\
\text { MCHC } Y_{7}: \text { RDW } Y_{8}: \text { Trombosit }(\mathrm{PLT})^{\wedge}, Y_{9}: \text { Limfosit, } Y_{10}: \text { Monosit, } Y_{11}: \text { Neutrofil, } Y_{12}: \text { Eosinofil, } Y_{13}: \text { Basofil } \\
\left.{ }^{* *}\right) \text { Organ Hati }: Y_{1}: \text { SGOT/AST, } Y_{2}: \text { SGPT/ALT, } Y_{3}: \text { Cholesterol, } Y_{4}: \text { Trigliserida, } Y_{5}: \text { HDL Chol Direk, } Y_{6}: \\
\text { LDL Chol Direk } Y_{7}: \text { Rasio LDL/HDL }\end{array}$} \\
\hline
\end{tabular}

Berdasarkan Tabel 2 diperoleh bahwa variabel yang memiliki nilai $p$-value $<0.05$, memberikan informasi yang signifikan terhadap model terutama pada organ darah antara lain $Y_{1}$, $Y_{2}, Y_{3}, Y_{5} . Y_{6}, Y_{7}, Y_{8}, Y_{9}, Y_{12}$. Dari variabel yang secara signifikan tersebut, selanjutnya akan dihitung nilai optimalnya.

\subsection{Perhitungan Nilai Optimal}

Perhitungan nilai optimal dilakukan menggunakan rancangan komposit untuk membangun model response surface ordo kedua. Agar rancangan komposit yang digunakan memiliki sifat ketelitian yang seragam maka perlu ditetapkan banyaknnya ulangan pada titik pusat. Dalam kasus ini banyaknya ulangan pada titik pusat yaitu 5 , dengan $k=2$ maka $n_{0}(\mathrm{ks})=$ 5 , nilai $\alpha$ untuk $k=2$ adalah $2^{k / 4}=2^{2 / 4}=1.4142$. 
Maka diperoleh matriks rancangan untuk percobaan dua faktor yang menggunakan rancangan komposit pusat dengan sifat ketelitian seragam dispesifikasikan seperti matriks D berikut:

$$
\left[\begin{array}{cc}
-1 & -1 \\
1 & -1 \\
-1 & 1 \\
1 & 1 \\
-1.4142 & 0 \\
1.4142 & 0 \\
0 & -1.4142 \\
0 & 1.4142 \\
0 & 0 \\
0 & 0 \\
0 & 0 \\
0 & 0 \\
0 & 0
\end{array}\right]
$$

Penentuan Taraf Faktor yang Bersesuaian dengan Titik Pusat

i. Faktor Meniran dengan titik pusat $\frac{50+100}{2}=75$ kode $X_{1}=0$

ii. Faktor Seledri dengan titik pusat $\frac{50+100}{2}=75$ kode $X_{2}=0$

Penentuan Hubungan antara Variabel Kode $X_{1}, X_{2}$, dan Variabel Asli

i. $\quad X_{1}=\frac{\text { Meniran-75 }}{50}$, sehingga Meniran $=50 X_{1}+75$

ii. $\quad X_{2}=\frac{\text { Seledri-75 }}{50}$, sehingga Seledri $=50 X_{2}+75$

Penentuan Taraf Faktor yang Bersesuaian dengan Nilai-nilai $\alpha$

Untuk $X_{1}=-1.4142$, maka Meniran $=50(-1.4142)+75=4.29$

Untuk $X_{1}=1.4142$, maka Meniran $=50(1.4142)+75=145.71$

Untuk $X_{2}=-1.4142$, maka Seledri $=50(-1.4142)+75=4.29$

Untuk $X_{2}=1.4142$, maka Seledri $=50(1.4142)+75=145.71$

\subsection{Penentuan Titik $X_{1}, X_{2}$ yang mengoptimalkan Nilai Respon}

Dari serangkaian proses pengujian pada variabel $Y_{1}, Y_{2}, Y_{3}, Y_{5} . Y_{6}, Y_{7}, Y_{8}, Y_{9}, Y_{12}$ dalam organ darah, dihasilkan variabel $Y_{9}$ dan $Y_{12}$ merupakan variabel yang memenuhi pada komponen darah. Lebih lanjut variabel dependent $Y_{9}$ dan $Y_{12}$ juga memenuhi serangkaian uji IIDN antara lain uji residual heteroskedaktisitas, uji autokorelasi dan uji normalitas, hasil perhitungan disajikan dalam gambar di bawah :
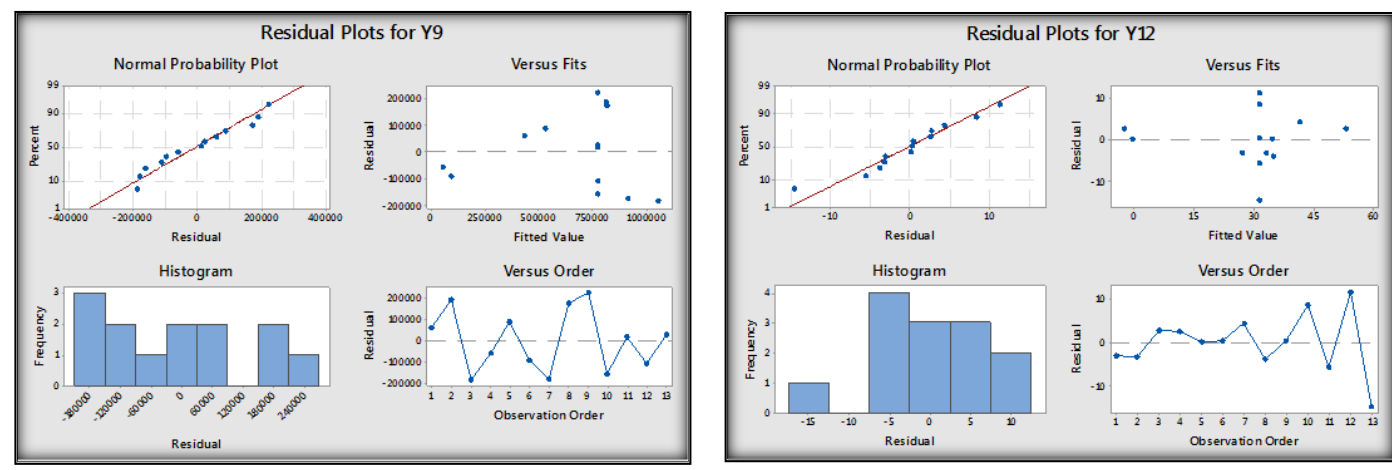

Gambar 1 Plot IIDN Variabel Dependent $Y_{9}$ dan $Y_{12}$ 
Dari Gambar 1 dapat ditarik kesimpulan bahwa untuk variabel dependent $Y_{9}$ dan $Y_{12}$ memenuhi uji IIDN. Selanjutnya dari uji yang memenuhi akan dicari nilai respon yang optimal. Adapun akan di cek terlebih dahulu syarat perlu sebagai berikut:

variabel $Y_{9}=778000-155455 X_{1}-34099 X_{2}-232500 X_{1}^{2}+46500 X_{2}^{2}-345000 X_{1} X_{2}$, apabila dideferensialkan untuk memenuhi syarat perlu, maka diperoleh titik stasioner $X_{1}=-0.1615916066$ dan $X_{2}=-0.2327968202$. Selanjutnya, apabila nilai-nilai stasioner tersebut di subtitusikan pada persamaan regresi $Y_{9}=778000-155455 X_{1}-34099 X_{2}-232500 X_{1}^{2}+$ $46500 X_{2}^{2}-345000 X_{1} X_{2}$ akan diperoleh output maksimum sebesar $1020611.351 \approx 1020611$.

Secara visual dapat disajikan pada gambar berikut :

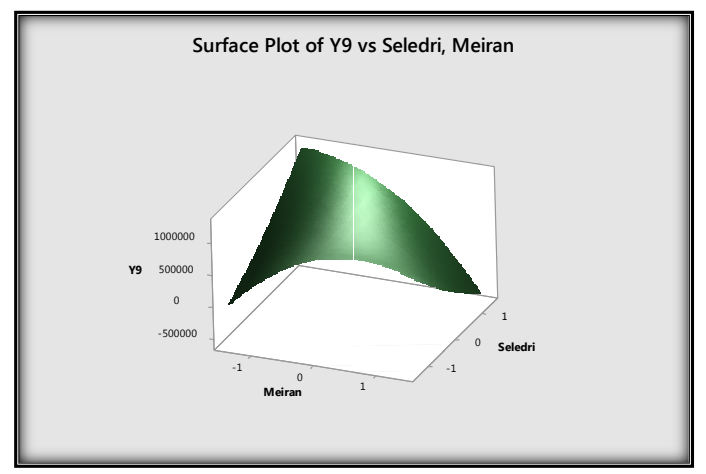

Gambar 2. Plot response surface Variabel Dependent $Y_{9}$.

Dengan mendifferensialkan persamaan pada variabel $Y_{12}$ akan diperoleh titik stasioner $X_{1}=-0.3575542123$ dan $X_{2}=-0.4717853288$. Selanjutnya, apabila nilai-nilai stasioner tersebut pada persamaan regresi $Y_{12}=31.60-12.44 X_{1}-2.40 X_{2}-7.17 X_{1}^{2}+3.33 X_{2}^{2}-15.50 X_{1} X_{2}$ sehingga diperoleh output maksimum sebesar $34.39012959 \approx 34$. Secara visual dapat disajikan pada gambar berikut :

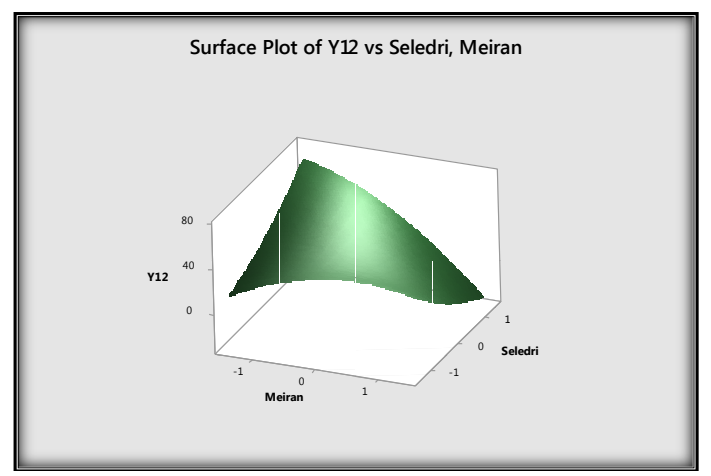

Gambar 3. Plot response surface Variabel Dependent $Y_{12}$

Selanjutnya akan diperiksa syarat cukup apakah titik stasioner itu bersifat maksimum dengan cara memeriksa syaraf cukup. Untuk variabel dependen $Y_{9}=778000-155455 X_{1}-$ $34099 X_{2}-232500 X_{1}^{2}+46500 X_{2}^{2}-345000 X_{1} X_{2}$, selanjutnya dibentuk matriks Hessian sebagai berikut :

$$
H=\left[\begin{array}{cc}
-465000 & -345000 \\
-345000 & 93000
\end{array}\right]
$$

dan diperoleh nilai determinan utama $\operatorname{Det}|H|=-1.6227 \times 10^{11}$. 
Berdasarkan persamaan pada penentuan variabel kode dan variabel asli, yaitu Meniran $=50 X_{1}+75$ dan Seledri $=50 X_{2}+75$ maka diperoleh, Meniran $=66.92041967 \approx 67$ dan Seledri $=63.36015899 \approx 63$.

Akan diperiksa pula syarat perlu untuk variabel $Y_{12}=31.60-12.44 X_{1}-2.40 X_{2}-7.17 X_{1}^{2}+$ $3.33 X_{2}^{2}-15.50 X_{1} X_{2}$, diperoleh matriks Hessian sebagai berikut:

$$
H=\left[\begin{array}{cc}
-14.34 & -15.50 \\
-15.50 & 6.66
\end{array}\right]
$$

dengan nilai determinan utama yaitu $\operatorname{Det}|H|=-335.7544$. diperoleh, Meniran $=$ $57.12228939 \approx 57$ dan Seledri $=51.41073356 \approx 51$.

\section{Kesimpulan}

Nilai optimum kombinasi daun Meniran dan daun Seledri menggunakan metode Respon Surface terdapat pada organ darah pada komponen Trombosit $\left(\boldsymbol{Y}_{\mathbf{9}}\right)$ dan komponen Neutrofil $\left(\boldsymbol{Y}_{\mathbf{1 2}}\right)$. Pada komponen trombosit yang memberikan hasil optimum sebesar 1020611 / $\mu l$ dengan kombinasi daun Meniran sebesar 67 mg/ BB dan daun sebesar 63 $\mathrm{mg} / \mathrm{BB}$ dan pada komponen Neutrofil memberikan hasil optimal sebesar $34 \mathrm{mcl}$ dengan kombinasi daun Meniran sebesar 57 mg/ BB dan Seledri sebesar 51 mg/ BB.

\section{Ucapan Terima Kasih}

Ditujukan kepada Universitas Ahmad Dahlan yang memberikan pendanaan pada penelitian ini.

\section{Daftar Pustaka}

[1] Fitriadan T, Saputra O, "Khasiat Daun Seledri Terhadap Tekanan Darah Tinggi Pada Pasien Hiperkolestrolemia Majority, Vol 5, No 2, pg 120.

[2] Nugraheni SS, "Ekstrak Akar, Batang, Dan Daun Herba Meniran Dalam Menurunkan Kadar Glukosa Darah,"Kemas, Vol 8 No 1 (2012), pg 51-59, 2012.

[3] Putra AR, Guritno A, "pencahayaan, kebisingan dan temperatur dengan Metode Respon Permukaan," Jurnal Sistem dan Manajemen Industri Vol 1 No 1 Juli 2017, 111.

[4] Ahmed D, Kasorang S, Khadir BA, Yousif BE, “Application of Response surface Methodology to Predict Oil-Film Friction in Journal Bearing," Applied Mechanics and Materials 393.

[5] Pakem GK, Ginting KB, Kleden MA, “ Penerapan Metode Respon Permukaan Dalam Optimalisasi Laba Usaha Pertanian Tanaman Kangkung Darat", Jurnal Diferensial, Volume 01, Nomor 01, November, 2019.

[6] Nurmiah S dkk, "Aplikasi Response surface Methodology Pada Optimalisasi Kondisi Proses Pengolahan Alkali Treated Cottonii (ATC)", JPB Kelautan dan Perikanan Vol. 8 No. 1 Tahun 2013: 9-22.

[7] Gaspersz, V." Teknik Analisis dalam Penelitian Percobaan,". Bandung. Tarsito Bandung.

[8] Ratnawati ES, dkk, "Aplikasi Response surface Methodology (RSM) pada Optimasi Ekstraksi Kalsium Tulang Lele", Jurnal Perikanan Universitas Gadjah Mada 20 (1) 2018: 41-48. 
[9] Rangkuti EM, “Aplikasi Response surface Methodology (RSM) Untuk Mempersingkat Waktu Pengeringan Sheet di Pabrik Pengolahan Sheet PTPN III Kebun Sarang Giting", Jurnal Sistem Teknik Industri, Vol 18. No. 2, Juli 2016

[10] Montgomery, “Design and Analysis of Experiment," Chapter 11, pg 427, 2001 